\title{
Isolasi dan Karakterisasi Bakteri Penghasil Bioetanol dari Lingkungan Industri Arak di Desa Tri Eka Buana, Kecamatan Sidemen, Karangasem Bali Isolation and Characterization of Bioethanol-Producing Bacteria from the Arak Industry of Environment in the Tri Eka Buana Village, Sidemen District, Karangasem Bali
}

\section{Awang Bagaskara, I Made Mahaputra Wijaya*, Nyoman Semadi Antara}

PS Teknologi Industri Pertanian, Fakultas Teknologi Pertanian, Universitas Udayana, Kampus Bukit Jimbaran, Badung, Kode pos : 80361; Telp/Fax : (0361) 701801.

Diterima 30 Desember 2019 / Disetujui 22 Januari 2020

\begin{abstract}
This research aimed to determine the ability of each bacterial isolate to produce ethanol, isolate and characterize bacteria that have the ability to produce potential ethanol from lau and air in the Arak Industry of environment in the Tri Eka Buana Village, Sidemen District, Karangasem Bali. Samples were obtained from 3 Hamlets in Tri Eka Buana Village. Bacteria were taken from lau before fermentation, during fermentation, and after fermentation. Bacteria from air were taken from the fermentation, distillation, and under the coconut tree and the variation of time is 15, 30, and 60 minutes of exposure. Bacteria from lau were isolated by growing on growth media, periodically (after 30, 60, 90, 120, and 150 seconds) the isolates were taken from suspension to be inoculated in growth media for gas production. Isolation was carried out using YEPD-fluconazole media to obtain pure isolates. The fluconazole concentration used was $0,2 \mathrm{~g} / \mathrm{L}$. Pure isolates were then carried out qualitative tests for gas production and quantitative tests with alcohol oxidation reactions. The results of UV-Visible spectrophotometry, there were 6 best isolates and then fermented in YEPD media on a scale of $900 \mathrm{~mL}$ for 10 days. The fermentation results were then distilled using a reflux distilator. BU3.111E1 isolates are determind the best isolates with 8,50\% brix ethanol. The BU3.111E1 were obtained from air bacteria in Pungutan Hamlet, place of sampling during the fermentation process for 15 minutes. From the characterization results, isolate BU3.111E1 was Gram positive bacteria, basil bacteria, motile bacteria, and catalase negative. This study proved that the bacteria had the ability to produce ethanol. Keyword: isolation, bioethanol, arak, bacteria, UV-Visible spectrophotometry
\end{abstract}

\footnotetext{
*Korespondensi Penulis:

Email : mahaputrawijaya@unud.ac.id
} 


\section{PENDAHULUAN}

Bioetanol merupakan cairan biokimia yang digunakan sebagai salah satu bahan bakar alternatif yang memiliki beberapa kelebihan dibandingkan bahan bakar minyak bumi, yaitu memiliki kandungan oksigen $\left(\mathrm{O}_{2}\right)$ yang lebih tinggi, bernilai oktan lebih tinggi yaitu 118 dan lebih ramah lingkungan karena menghasilkan emisi gas karbon monoksida (CO) sekitar 19-25\% lebih rendah dibandingkan dengan bahan bakar minyak (Senam, 2009). Bioetanol dapat diproduksi melalui proses fermentasi yang memanfaatkan bantuan mikroorganisme. Mikroorganisme yang banyak digunakan dalam proses fermentasi adalah khamir dan bakteri (Budiyanto, 2004). Saat ini, Saccharomyces cerevisiae dari golongan khamir digunakan sebagai mikroorganisme penghasil etanol utama di seluruh dunia. Namun Saccharomyces cerevisiae memiliki beberapa kekurangan, diantaranya adalah produksi biomassa yang tinggi dan tidak tahan dengan konsentrasi tinggi dari etanol yang dihasilkan (Mohseni et al., 2016), sehingga bakteri memiliki potensi dalam memproduksi etanol lebih efektif dan efisien (Dien et al., 2003). Salah satu bakteri berpotensi untuk menghasilkan etanol dalam proses fermentasi yaitu bakteri Zymomonas mobilis. Penelitian Gunasekaran dan Raj (1999) menemukan bahwa bakteri Zymomonas mobilis mempunyai beberapa kelebihan dibandingkan dengan khamir, antara lain mempunyai toleransi suhu yang tinggi, kemampuan untuk tumbuh secara anaerob, kemampuan untuk mencapai konversi yang lebih tinggi, mampu menghasilkan etanol mencapai $92 \%$, dan tahan terhadap kadar etanol yang lebih tinggi (Roger and Adelberg, 1982).

Salah satu proses fermentasi tradisional di Indonesia yang memanfaatkan mikroorganisme untuk menghasilkan alkohol yaitu arak. Menurut Dinas Industri dan
Perdagangan Kabupaten Karangasem (2015) bahwa Kecamatan Sidemen merupakan kecamatan yang memiliki jumlah industri arak terbanyak di Kabupaten Karangasem. Desa Tri Eka Buana merupakan salah satu desa yang memiliki jumlah industri arak terbanyak dengan 90\% dari jumlah kepala keluarga memiliki mata pencaharian tersebut. Masyarakat Bali menambahkan lau (salah satunya serabut kelapa yang sudah disuwir dan diikat) pada nira saat proses pembuatan arak sebagai sumber mikroorganisme dengan menggunakan tangan pekerja yang tidak aseptis (Simatupang et al., 2018). Selain itu, diperkirakan mikroorganisme di udara yang terdapat pada lingkungan industri arak tersebut juga dapat mempengaruhi pertumbuhan mikroorganisme pada lau, sehingga diperkirakan terdapat beragam bakteri yang memiliki kemampuan mengkonversi zat gula menjadi etanol. Sebelumnya, telah dilakukan penelitian serupa oleh Simatupang et al. (2018), bahwa nilai total etanol yang diperoleh dari hasil fermentasi oleh bakteri pada lau cenderung kecil. Hal ini terjadi karena bakteri yang diisolasi telah banyak berkurang akibat serabut kelapa yang digunakan memiliki kandungan tanin, polifenol, dan flavonoid yang dapat menjadi anti bakteri alami (Wulandari et al., 2018).

Penelitian ini bertujuan untuk mengetahui kemampuan masing-masing isolat bakteri dalam memproduksi bioetanol, menentukan isolat bakteri yang memiliki kemampuan menghasilkan bioetanol tertinggi, dan menentukan karakteristik bakteri potensial yang diisolasi dari lingkungan industri arak di Desa Tri Eka Buana, Kecamatan Sidemen, Karangasem Bali.

\section{METODE PENELITIAN}

Tempat dan Waktu Penelitian 
Pengambilan sampel dilakukan pada tiga dusun yang terdapat di Desa Tri Eka Buana, Kecamatan Sidemen, Karangasem Bali. Lokasi pengambilan sampel antara lain Dusun Betenan, Dusun Duuran, dan Dusun Pungutan. Sampel kemudian dibawa ke Laboratorium Bioindustri dan Lingkungan Fakultas Teknologi Pertanian, Universitas Udayana untuk diteliti. Waktu pelaksanaan penelitian dimulai Mei sampai Oktober 2019.

\section{Bahan dan Alat}

Bahan yang digunakan yaitu lau, media pertumbuhan yang digunakan adalah Yeast Extract Peptone Dextrose (YEPD) atau Zymomonas Medium Broth dengan bahan $10 \mathrm{~g} / \mathrm{L}$ yeast extract (merk KGaA), 10 $\mathrm{g} / \mathrm{L}$ peptone (merk $\mathrm{KGaA}), 20 \mathrm{~g} / \mathrm{L}$ dextrose (merk PT. Brataco), 0,5 g/L magnesium sulfate $\left(\mathrm{MgSO}_{4} 7 \mathrm{H}_{2} \mathrm{O}\right)$ (merk $\mathrm{KGaA}$ ) dan akuades (Hanidah et al., 2016). YEPDA dibuat dengan penambahan $15 \mathrm{~g} / \mathrm{L}$ agar (merk Himedia). Media selektif dibuat dengan penambahan $0,2 \mathrm{~g} / \mathrm{L}$ flukonazol sebagai antifungi (Warman, 2017). Bahan pengujian yaitu hidrogen peroksida $\left(\mathrm{H}_{2} \mathrm{O}_{2}\right)$, $\mathrm{NaCl}$, gliserol $40 \%$, potasium dikromat $\left(\mathrm{K}_{2} \mathrm{Cr}_{2} \mathrm{O}_{7}\right)$, media sulfide indole motility (SIM), bahan pewarnaan Gram terdiri dari kristal violet, lugol, safranin, dan alkohol $96 \%$.

Alat yang digunakan pada penelitian ini antara lain botol kaca (Duran), gelas ukur (Pirex-Iwaki), timbangan, magnetic stirrer (IKA C-MAG HS 7), gunting, sarung tangan, plastik, laminar flow (Wina), inkubator (Memmert), vortex (Thermo Scientific), pipet mikro (Socorex), bunsen, jarum ose, cawan petri (Pirex-Iwaki), tabung reaksi (Pyrex), Erlenmeyer (Pirex-Iwaki), labu ukur (Pirex-Iwaki), shaker (H-MSR), mikroskop, spektrofotometri $U V$-visible (Biochrome S-26), autoklaf (Daihan Scientific), sentrifuge (Herolab), destilator, tip biru, tip kuning, aluminium foil, eppendorf, freezer, dan kapas.

\section{Rancangan Penelitian}

Penelitian ini merupakan penelitian eksplorasi-eksperimental yang bertujuan untuk mengisolasi dan mengkarakterisasi bakteri penghasil bioetanol dari tiga Dusun yang terdapat di Desa Tri Eka Buana, Sidemen, Karangasem Bali. Sampel dari lau diambil secara aseptis dari bahan baku sebelum fermentasi, saat fermentasi, dan serabut kelapa kering setelah fermentasi. Sampel lau yang diperoleh dari Dusun Betenan dan Dusun Duuran yaitu masingmasing 2 buah. Sampel tersebut berasal dari serabut kelapa sebelum fermentasi dan saat fermentasi. Sedangkan di Dusun Pungutan diperoleh sampel lau sebanyak 3 buah, yaitu serabut kelapa sebelum fermentasi, saat fermentasi, dan serabut kelapa kering setelah fermentasi, sehingga total sampel dari lau yang diperoleh adalah 7 buah. Sedangkan sampel bakteri dari udara diambil dari tiga Dusun dengan tiga titik berbeda pada setiap Dusun, yaitu tempat proses fermentasi, tempat penyulingan, dan di bawah pohon kelapa yang digunakan untuk pengambilan nira. Setiap titik pengambilan sampel bakteri dari udara dilakukan tiga variasi waktu pemaparan menggunakan cawan petri yaitu 15, 30, dan 60 menit dengan dua pengulangan, sehingga total sampel bakteri dari udara yang diperoleh adalah 54 cawan petri yang berasal dari masing-masing 18 cawan petri dari setiap Dusun.

\section{Pelaksanaan Penelitian}

Sampel dari lau diisolasi dengan cara dipotong kecil $\pm 1 \mathrm{~cm}$ dan ditimbang $1 \mathrm{~g}$ untuk dicampurkan pada media YEPD sebanyak $5 \mathrm{~mL}$ dalam tabung reaksi dan divortex. Secara periodik (setelah 30, 60, 90, 120, dan 150 detik) divortex dan diambil 0,2 $\mathrm{mL}$ dari suspensi untuk ditumbuhkan pada media YEPD-flukonazol untuk menampung gas hasil fermentasi, sehingga isolat yang diisolasi dari bakteri lau sebanyak 35 isolat. Sedangkan bakteri dari udara diisolasi 
dengan cara diambil lima koloni yang tumbuh berbeda setelah inkubasi pada setiap cawan petri kemudian dicampurkan pada media YEPD-flukonazol untuk menampung gas hasil fermentasi, sehingga isolat yang diisolasi dari udara sebanyak 270 isolat. Fermentasi dilakukan selama 72 jam pada suhu $30{ }^{\circ} \mathrm{C}$. Gas yang dihasilkan dalam proses fermentasi diasumsikan $\mathrm{CO}_{2}$. Tabung reaksi diberi plastik panjang dan disegel agar kedap udara sebagai tempat penampungan gas hasil fermentasi dan untuk mengamati volume gas yang dihasilkan saat fermentasi. Hasil pengamatan produksi gas yang diperoleh diklasifikasikan menjadi dua kelompok yaitu kelompok gas banyak dan gas sedang. Isolat yang menghasilkan gas banyak ditandai dengan plastik yang mengembang lebih tinggi dan keras saat ditekan. Untuk kelompok isolat gas sedang dilihat dari gas yang dihasilkan pada plastik penampung mengembang tinggi namun tidak keras seperti gas banyak saat ditekan.

Isolat yang menghasilkan gas disebar dengan metode streak plate pada media YEPDA, untuk memperoleh kultur murni dilakukan dengan metode quadrant streak pada media YEPDA-flukonazol. Isolat yang telah murni dilakukan seleksi dengan uji kualitatif untuk menampung gas yang diasumsikan $\mathrm{CO}_{2}$ kembali. Isolat terseleksi ini dilakukan uji kuantitatif untuk mereaksikan etanol dengan potasium dikromat (Simbolon et al., 2018). Uji kuantitatif etanol dilakukan untuk mendapatkan isolat terbaik dengan cara pemindaian menggunakan spektrofotometer $U V$-visible. Sebelum pengujian terhadap isolat, dilakukan pembuatan grafik standar untuk menentukan perbandingan terbaik dan mengetahui panjang gelombang absorbansi. Pembuatan grafik standar terdiri dari penambahan akuades + potasium dikromat, etanol $20 \%$ + potasium dikromat, media YEPD-flukonazol yang mengandung etanol $20 \%$ + potasium dikromat (Simbolon et al.,
2018). Dari hasil uji kuantitatif, isolat terbaik dilakukan fermentasi produksi etanol dengan volume media sebanyak $900 \mathrm{~mL}$. Media yang digunakan pada tahap fermentasi adalah media YEPD dengan kadar glukosa $20 \%$. Fermentasi dilakukan selama 10 hari. Setelah 10 hari fermentasi, media fermentasi didistilasi menggunakan distilator refluks untuk mendapatkan total etanol (Simatupang et al., 2018). Isolat terbaik dilakukan pengamatan makroskopik dan mikroskopik. Diagram alir penelitian isolasi dan karakterisasi bakteri penghasil bioetanol dapat dilihat pada Gambar 1.

\section{Variabel yang Diamati}

Variabel yang diamati yaitu gas hasil fermentasi (Simatupang et al., 2018), nilai absorbansi pada uji kuantitatif (Simbolon et al., 2018), total etanol (Simatupang et al., 2018), bentuk, permukaan/elevasi, tepi, dan warna koloni dengan pengamatan makroskopik (Dwijoseputro, 1989) dan pewarnaan Gram (Pelczar and Chan, 2008) serta biokimia (motilitas dan katalase) dengan pengamatan mikroskopik (Cowan, 2004).

\section{Analisis Data}

Aplikasi yang digunakan pada penelitian ini yaitu Igor dan MS. Excel untuk menganalisis data yang diperoleh. Hasil analisis data kemudian disajikan dalam bentuk grafik dan tabel lalu dibahas secara deskriptif.

\section{HASIL DAN PEMBAHASAN}

\section{Gas Hasil Fermentasi}

Hasil uji konfirmasi gas dari 35 isolat lau, didapatkan sebanyak 10 isolat yang menghasilkan gas, isolat yang tidak menghasilkan gas berasal dari serabut kelapa saat fermentasi di Dusun Duuran dan Dusun Pungutan. Sedangkan pada isolat bakteri udara, dari 270 isolat diperoleh 80 isolat yang 
menghasilkan gas pada plastik penampung, isolat yang tidak menghasilkan gas yaitu bakteri yang diperoleh dari tempat penyulingan selama 30 menit di Dusun
Betenan, di tempat fermentasi selama 15 menit di Dusun Duuran, dan di bawah pohon kelapa selama 60 menit di Dusun Duuran. Isolat yang diperoleh sebanyak 90 isolat.

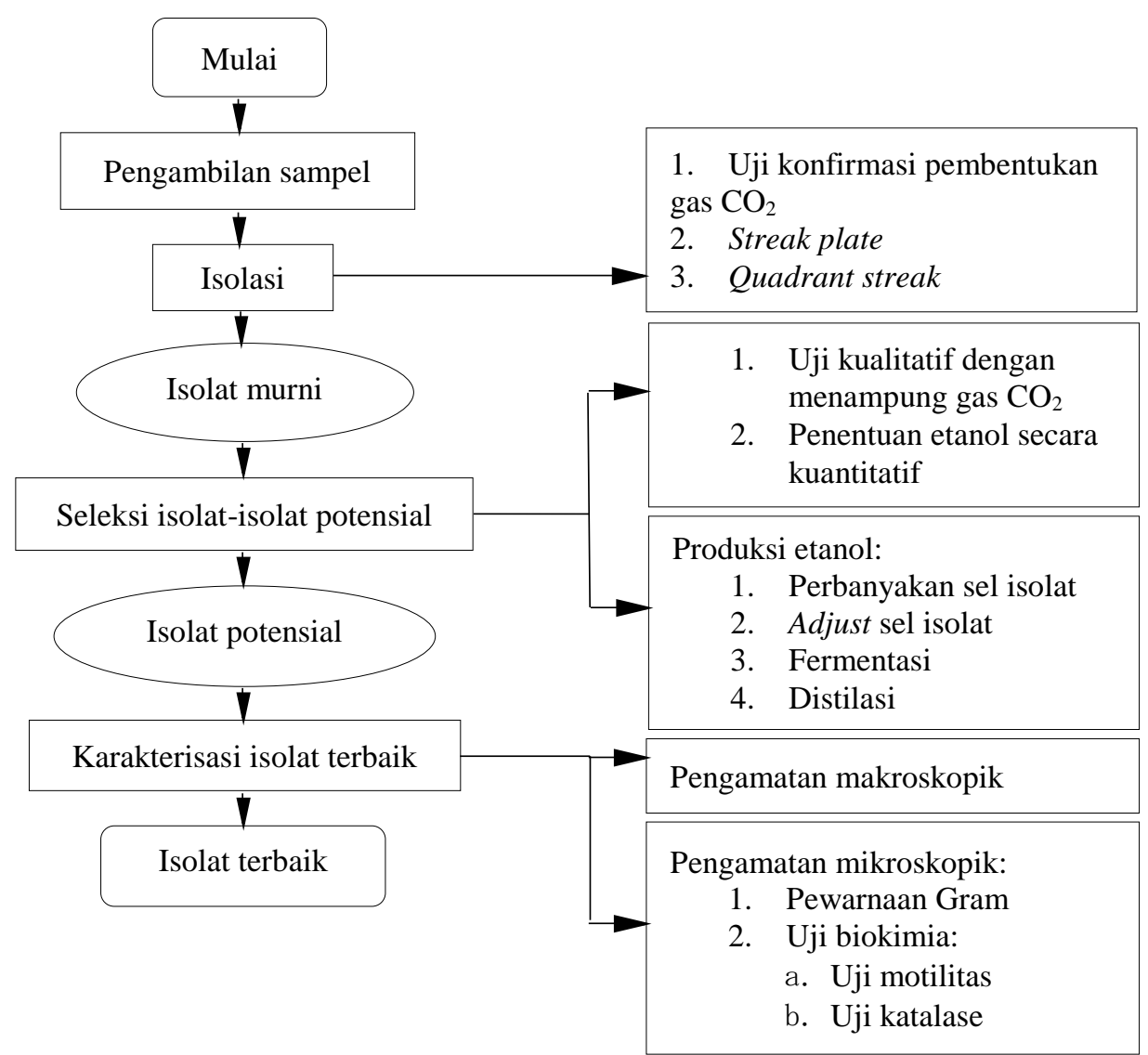

Gambar 1. Diagram alir prosedur penelitian, isolasi dan karakterisasi bakteri

Isolat yang lolos uji konfirmasi gas sebanyak 183 isolat. Isolat yang diperoleh tumbuh dengan kemampuan pertumbuhan yang berbeda-beda seperti tumbuh sangat sedikit, tumbuh sedikit, tumbuh banyak, dan tumbuh sangat banyak. Isolat murni tersebut diseleksi dengan cara uji kualitatif dalam memproduksi gas yang diasumsikan $\mathrm{CO}_{2}$. Proses fermentasi glukosa menghasilkan alkohol dan gas $\mathrm{CO}_{2}$ dengan perbandingan 1:1 mol (Hambali et al., 2007). Isolat yang diperoleh dari hasil seleksi gas sebanyak 113 isolat. Secara umum, hasil pengamatan morfologi memiliki bentuk circular (bulat), dengan diameter $1 \mathrm{~mm}$, berwarna bening kekuningan, tepian entire (berbentuk melengkung rapi), dan elevasi convex (permukaan sedikit menonjol atau hampir rata).

\section{Nilai Absorbansi Pada Uji Kuantitatif}

Grafik pemindaian absorbansi dapat dilihat pada Gambar 2. 


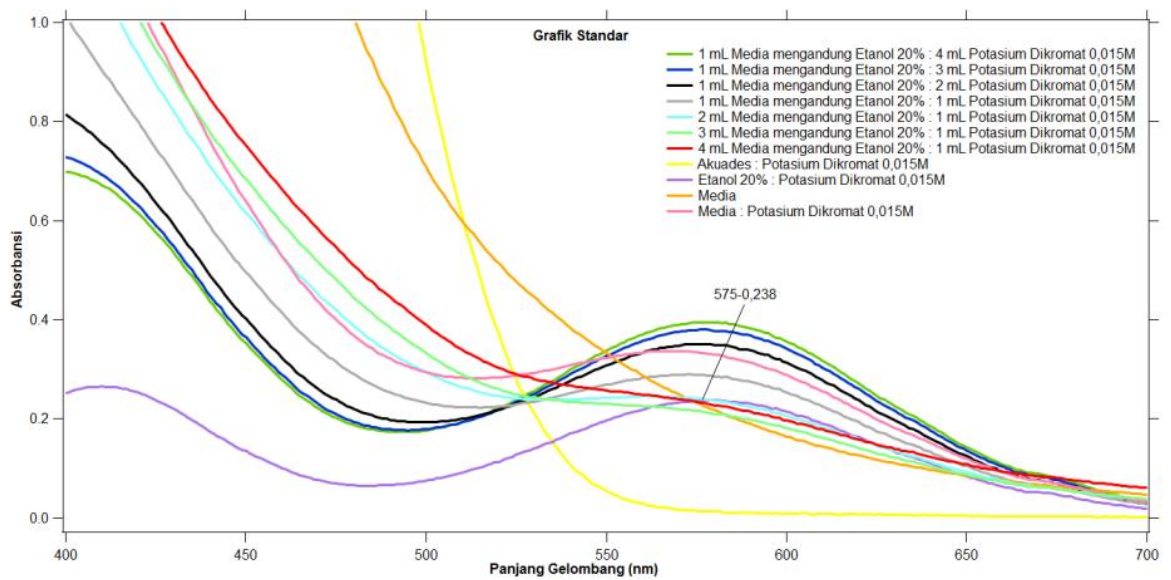

Gambar 2. Hasil pemindaian absorbansi dari campuran larutan etanol dan kalium dikromat

Grafik di atas (Gambar 2), dilakukan 7 percobaan dalam pencampuran media mengandung etanol $20 \%$ dengan potasium dikromat (Simbolon et al., 2018). Dapat dilihat bahwa perbandingan 2:1 antara media mengandung etanol + potasium dikromat (garis biru muda) memiliki absorbansi yang hampir sama reaksi antara etanol + potasium dikromat (garis ungu). Berdasarkan hal tersebut, perbandingan volume yang digunakan antara supernatan dan potasium dikromat adalah 2:1. Pada reaksi lain dapat dilihat bahwa media (garis orange) yang awalnya nilai absorbansi tidak naik, setelah direaksikan antara media + potasium dikromat (merah muda) mengalami perubahan absorbansi, hal tersebut dapat disimpulkan bahwa media dapat bereaksi dengan potasium dikromat yang menyebabkan perubahan nilai absorbansi. Hasil uji kuantitatif pada 113 isolat dapat dilihat pada Gambar 3.

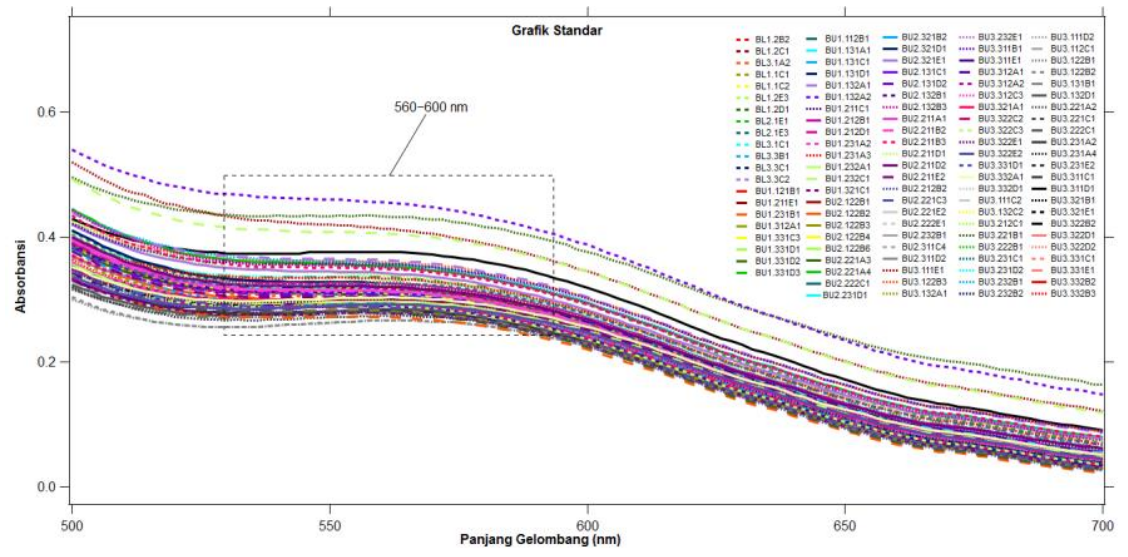

Gambar 3. Hasil uji kuantitatif produksi etanol dari 113 isolat yang diisolasi dari bakteri lau dan udara

Grafik di atas (Gambar 3) menunjukkan bahwa pembacaan absorbansi tertinggi dapat dilakukan pada panjang gelombang 560-600 nm. Hal ini sesuai dengan penelitian Simbolon et al. (2018) untuk mengetahui nilai absorbansi dari etanol dengan potasium dikromat dibaca pada panjang gelombang 560-600 $\mathrm{nm}$. Setelah mendapatkan hasil pemindaian pada 113 isolat, dipilih enam isolat potensial berdasarkan absorbansi tertinggi. Enam isolat potensial tersebut berasal dari masing-masing tiga isolat bakteri dari lau dan udara. Hasil pemilihan enam isolat terbaik tersebut kemudian dipindai panjang gelombang yang memperlihatkan absorbansi tertinggi (Gambar 4). 


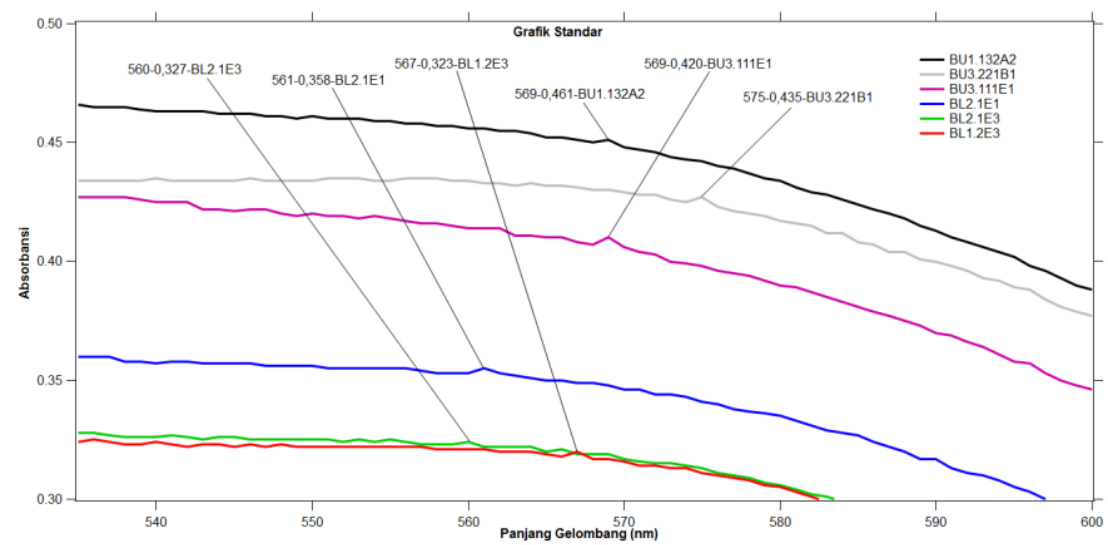

Gambar 4. Grafik hasil pemindaian etanol hasil produksi dari 6 isolat terbaik

Hasil pemindaian dari enam isolat tersebut, terlihat bahwa tiga isolat bakteri dari udara memiliki nilai absorbansi lebih tinggi dibandingkan isolat bakteri dari lau (Tabel 1).

Tabel 1. Isolat potensial hasil uji kuantitatif

\begin{tabular}{cccc}
\hline Kode & Panjang gelombang $(\mathbf{n m})$ & Absorbansi & Keterangan \\
\hline BU1.132A2 & 569 & 0,461 & Produksi gas sedang \\
BU3.221B1 & 575 & 0,435 & Produksi gas banyak \\
BU3.111E1 & 569 & 0,420 & Produksi gas banyak \\
BL2.1E1 & 561 & 0,358 & Produksi gas sedang \\
BL2.1E3 & 560 & 0,327 & Produksi gas sedang \\
BL1.2E3 & 567 & 0,323 & Produksi gas sedang \\
\hline
\end{tabular}

Keterangan: BU: Bakteri Udara; BL: Bakteri Lau

Isolat dari kelompok produksi gas banyak diperoleh sebanyak dua isolat yang berasal dari bakteri udara, pada kelompok gas sedang diperoleh empat isolat. Pada tabel diatas, nilai absorbansi tidak linier dengan hasil uji kualitatif. Nilai absorbansi tertinggi berasal dari isolat BU1.132A2 dengan nilai absorbansi 0,461 yang berasal dari kelompok gas sedang. Menurut Richana (2011), proses fermentasi glukosa akan menghasilkan alkohol dan gas $\mathrm{CO}_{2}$, walaupun demikian gas yang dapat diukur volumenya hanya sekitar 70-80\%. Selain itu, gas $\mathrm{CO}_{2}$ yang terbentuk pada saat proses fermentasi dapat menghambat pertumbuhan isolat (Muin et al., 2015). Hal ini juga terjadi pada penelitian Simbolon et al. (2018) bahwa nilai absorbansi tertinggi dari uji kuantitatif berasal dari kelompok gas sedang, dimana isolat yang menghasilkan etanol tertinggi memperoleh nilai absorbansi lebih rendah. Hal tersebut dapat terjadi karena komposisi media pada saat inkubasi mempengaruhi reaksi oksidasi potasium dikromat. Maka dari itu, metode oksidasi menggunakan potasium dikromat menjadi indikator awal untuk kuantifikasi etanol karena metode ini kurang akurat dalam memperoleh etanol (Koshy et al., 2014).

Pada tiga isolat bakteri dari lau, dapat dilihat bahwa isolat terseleksi berdasarkan nilai absorbansi adalah lau yang diisolasi setelah 150 detik. Isolasi bakteri dari lau dilakukan dengan waktu yang berbeda-beda agar kandungan anti bakteri pada lau belum terlarut dalam media pertumbuhan. Tanin, polifenol, dan flavonoid merupakan zat anti gizi yang dapat ditemukan pada tumbuhan yang bersifat sebagai anti bakteri dan larut dalam pelarut organik seperti metanol, etanol, 
dan aseton (Muryati dan Nelfiyanti, 2015). Berdasarkan hasil tersebut, dapat dinyatakan bahwa tanin, polifenol, dan flavonoid pada serabut kelapa mengalami kelarutan yang cukup lama pada media, sehingga pada waktu 150 detik masih terdapat bakteri yang tumbuh pada media.

Supernatan yang dicampurkan dengan potasium dikromat akan terjadi reaksi perubahan warna. Perubahan warna terjadi setelah supernatan dan potasium dikromat diinkubasi selama 30 menit pada suhu ruang (Miskah et al., 2015). Reaksi perubahan warna yang terjadi yaitu dari jingga menjadi kuning kehijauan. Pada Tabel 1 dapat dilihat bahwa enam isolat dengan nilai absorbansi tertinggi dapat dibaca pada panjang gelombang 560-575 nm. Hal ini sesuai dengan pernyataan Balcerzak et al. (2008) bahwa warna kuning kehijauan saat dipindai menggunakan spektrofotometer $U V$-visible akan membentuk absorbansi pada panjang gelombang antara 560-580 nm. Reaksi perubahan warna dapat dilihat pada Gambar 5.

Tabel 2. Total etanol dari isolat terbaik hasil distilasi

\begin{tabular}{|c|c|c|c|c|c|}
\hline $\begin{array}{l}\text { Kode } \\
\text { Isolat }\end{array}$ & $\begin{array}{c}\text { Total padatan } \\
\text { terlarut awal } \\
(\% \text { brix })\end{array}$ & $\begin{array}{c}\text { Total padatan } \\
\text { terlarut akhir } \\
(\% \text { brix })\end{array}$ & $\begin{array}{c}\Delta \text { Total padatan } \\
\text { terlarut } \\
(\% \text { brix })\end{array}$ & $\begin{array}{c}\text { Total etanol } \\
(\mathrm{mL})\end{array}$ & $\begin{array}{c}\text { Total } \\
\text { etanol / } \\
\Delta \% \text { brix }\end{array}$ \\
\hline BU1.132A2 & $18,93 \pm 0,41$ & $18,56 \pm 0,20$ & 0,36 & $0,70 \pm 0,11$ & 1,91 \\
\hline BU3.221B1 & $18,93 \pm 0,30$ & $17,66 \pm 0,57$ & 1,26 & $6,47 \pm 0,22$ & 5,11 \\
\hline BU3.111E1 & $18,60 \pm 0,00$ & $17,26 \pm 0,30$ & 1,33 & $11,33 \pm 0,56$ & 8,50 \\
\hline BL2.1E1 & $18,80 \pm 0,20$ & $18,53 \pm 0,11$ & 0,26 & $1,12 \pm 0,24$ & 4,21 \\
\hline BL2.1E3 & $19,20 \pm 0,34$ & $18,00 \pm 0,72$ & 1,20 & $1,23 \pm 0,11$ & 1,03 \\
\hline BL1.2E3 & $18,60 \pm 0,00$ & $18,36 \pm 0,15$ & 0,23 & $1,54 \pm 0,17$ & 6,60 \\
\hline
\end{tabular}

Dari hasil produksi dapat dilihat bahwa total etanol tertinggi dihasilkan dari isolat BU3.111E1 yang berasal dari sampel bakteri udara di Dusun Pungutan dengan tempat pengambilan sampel saat fermentasi berlangsung selama 15 menit yaitu sebanyak $11,33 \mathrm{~mL}$. Hasil tersebut linier karena isolat BU3.111E1 berasal dari kelompok isolat dengan produksi gas banyak. Penurunan total

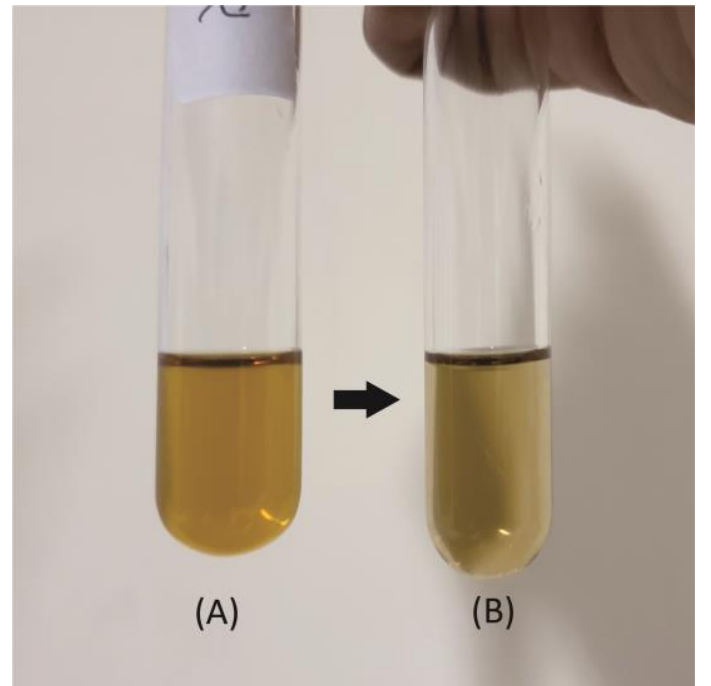

Gambar 5. (a) larutan potasium dikromat sebelum direaksikan dengan supernatan (warna jingga); (b) hasil reaksi antara supernatan dan potasium dikromat (warna

\section{Total Etanol} kuning kehijauan)

Total etanol yang diperoleh dari hasil distilasi pada media fermentasi dapat dilihat pada Tabel 2. 
(2019) bahwa selisih total padatan terlarut pada media fermentasi PYG menggunakan khamir mencapai $16 \%$ brix. Namun, selisih total padatan terlarut pada isolat BU3.111E1 cenderung rendah. Hal ini terjadi karena isolat tidak toleran terhadap kadar gula yang tinggi. Kadar glukosa yang digunakan saat fermentasi juga kemungkinan terlalu tinggi sehingga isolat jenuh dan menyebabkan proses penguraian gula pada proses fermentasi kurang sempurna.

Selain itu, pada Tabel 2 dapat dilihat adanya anomali data, dimana selisih total padatan terlarut $(\Delta \%$ brix $)$ pada isolat BL2.1E3 lebih besar tetapi menghasilkan nilai total etanol lebih kecil. Hal ini

disebabkan karena sel yang tidak toleran terhadap kadar alkohol yang tinggi, sehingga alkohol yang dihasilkan oleh bakteri selama proses fermentasi akan menghambat aktifitas dan pertumbuhan sel sehingga tidak dapat terfermentasi sempurna. Selain itu, diperkirakan bakteri mengalami inhibisi substrat yang menyebabkan sel mengalami stres dan metabolisme sel menurun (Neelakandan dan Usharani, 2009).

\section{Pengamatan Makroskopik dan Mikroskopik}

Hasil pengamatan makroskopik dan mikroskopik dapat dilihat pada Gambar 6.

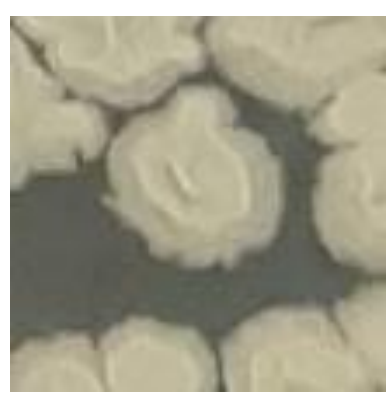

(a)

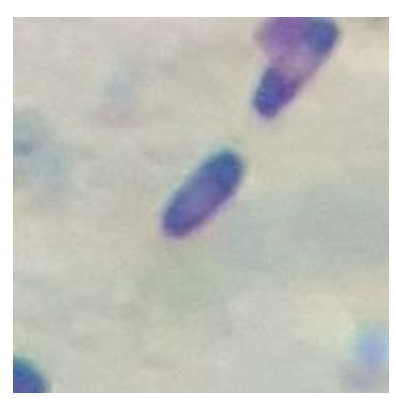

(b)

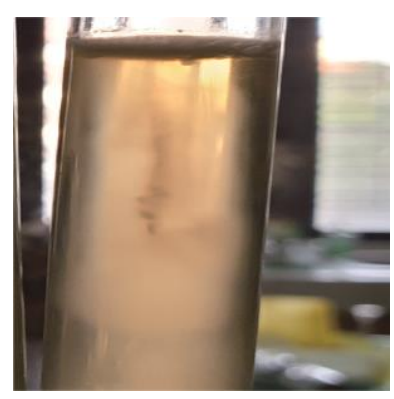

(c)

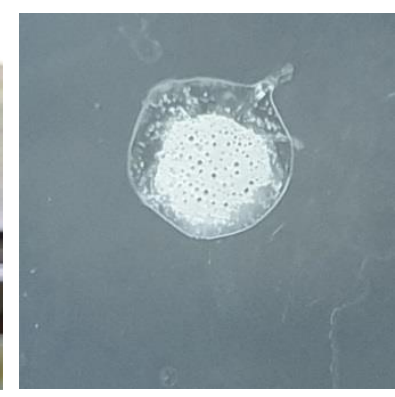

(d)

Gambar 6. (a) koloni; (b) bakteri Gram positif; (c) motil; (d) katalase negatif Hasil pengamatan makroskopik dan mikroskopik

Secara makroskopik, koloni BU3.111E1 memiliki bentuk rhizoid (seperti akar tanaman) dengan diameter $2 \mathrm{~mm}$, berwarna putih kekuningan, tepian lobate (berbetuk gerigi yang tidak beraturan dan besar), dan elevasi unbonate (permukaan menonjol dengan setitik ujung yang lebih menonjol). Pada pengamatan mikroskopik, dilakukan dengan pewarnaan Gram dan uji biokimia, dimana pada uji biokimia meliputi uji motilitas dan uji katalase.

Pada tahap pengamatan mikroskopik, hasil pengecatan Gram pada isolat BU3.111E1 yaitu bakteri golongan Gram positif yang berbentuk basil. Bakteri Gram positif dapat mempertahankan warna kristal violet karena memiliki dinding sel lebih tebal dan mengandung sedikit lipid (Pelczar and
Chan, 2008). Pada uji motilitas, isolat BU3.111E1 termasuk bakteri motil karena membentuk seperti akar pada media Sulfide Indole Motility (SIM) yang menandakan bahwa isolat potensial mempunyai alat gerak berupa flagel (Burrows, 2004). Pada pengamatan uji katalase, isolat tidak membentuk gelembung-gelembung udara yang mengindikasikan bahwa bakteri tersebut katalase negatif yang berarti bakteri ini bersifat anaerob. Berdasarkan karakteristik tersebut, bakteri BU3.111E1 berbeda dengan ciri-ciri bakteri Zymomonas mobilis.

\section{KESIMPULAN DAN SARAN}

\section{Kesimpulan}


Berdasarkan penelitian yang telah dilakukan maka dapat disimpulkan beberapa hal sebagai berikut:

1. Bakteri yang diisolasi dari Industri Arak di Desa Tri Eka Buana mempunyai kemampuan yang berbeda-beda untuk memproduksi etanol.

2. Bakteri BU3.111E1 memiliki kemampuan menghasilkan etanol tertinggi yaitu $8,50 \%$ brix. Isolat BU3.111E1 berasal dari sampel bakteri udara di Dusun Pungutan, tempat pengambilan sampel saat fermentasi berlangsung selama 15 menit.

3. Bakteri BU3.111E1 merupakan bakteri Gram positif berbentuk basil, motil, dan katalase negatif. Berdasarkan karakteristik tersebut, bakteri BU3.111E1 bukan merupakan bakteri Zymomonas mobilis. Bakteri yang diisolasi dari udara menghasilkan etanol lebih tinggi dibandingkan dengan bakteri yang diisolasi dari lau.

\section{Saran}

Berdasarkan hasil penelitian ini dapat disarankan beberapa hal sebagai berikut :

1. Perlu dilakukan penelitian lebih lanjut untuk mengetahui kadar glukosa optimum saat fermentasi pada isolat BU3.111E1.

2. Perlu dilakukan fermentasi menggunakan nira kelapa steril sebagai media fermentasi dengan isolat BU3.111E1 sebagai setater pengganti lau, dan menentukan konsentrasi isolat terbaik saat fermentasi.

\section{DAFTAR PUSTAKA}

Balcerzak, M., A. Tyburska, and E.S. Fuchsel. 2008. Selective determination of fe (iii) in fe (ii) samples by uvspectrophotometry with the aid of quercetin and morin. Acta Pharmaceutica. 5(8): 327-334.
Budiyanto, A.K. 2004. Mikrobiologi Terapan. Universitas Muhammadiyah Malang, Malang.

Burrows, W., J.M. Moulder, and R.M. Lewert. 2004. Textbook of Microbiology. W.B. Saunders Company, Philadelphia.

Cowan, S.T. 2004. Manual for the Identification of Medical Fungi. Cambridge University, London.

Dien, B.S., M.A. Cotta, and T.W. Jeffries. 2003. Bacteria engineered for fuel ethanol production: Current status. Appl. Microbiol. Biotechnol 63: 258-266.

Dinas Perindustrian dan Perdagangan Kabupaten Karangasem. 2015. Data Potensi Indag Tahun 2015. Karangasem, Bali.

Dwijoseputro, D. 1989. Dasar-Dasar Mikrobiologi. Djambatan. Surabaya.

Gunasekaran, P. and K. C. Raj. 1999. Ethanol fermentation technology-zymomonas mobilis. Current Science. 77(1): 56-68.

Hambali, E., S. Mujdalifah, A. Halomoan, Tambunan, A.W. Pattiwiri, dan R. Hendroko. 2007. Teknologi Bioenergi. Agromedia Pustaka, Jakarta.

Hanidah, I., R. Safitri, dan T. Subroto. 2016. Alternatif fermentasi bio-etanol dari bagas tebu oleh Zymomonas mobilis. Jurnal Penelitian Pangan. 1(1): 27-30.

Koshy, B. E., F. K. Pandey, and T. Bhatnagar. 2014. Quantitative estimation of bioethanol produced from lignocellulosic \& household wastes. International Journal of Life Sciences Research. 2 (4): 130-145.

Miskah, D., B. Tumanggor, dan F.P. Sinambela. 2015. Penambahan $\mathrm{K}_{2} \mathrm{Cr}_{2} \mathrm{O}_{7}$ terhadap waktu awal penyalaan pada biobriket dari 
campuran batubara dan tongkol jagung. Jurnal Teknik Kimia. 3(21): 37-49.

Mohseni, M., H. Ebrahimi, and M.J. Chaichi. 2016. Isolation and optimization of ethanol producing bacteria from natural environments of mazandaran province in Iran. Journal of Genetic Resources. 1(1): 35-44.

Muin, R., I. Hakim, dan A. Febriyansyah. 2015. Pengaruh waktu fermentasi dan konsentrasi enzim terhadap kadar bioetanol dalam proses fermentasi nasi aking sebagai substrat organik. Jurnal Teknik Kimia. 3(21): 59-69.

Muryati, dan Nelfiyanti. 2015. Pemisahan tanin dan HCN secara ekstraksi dingin pada pengolahan tepung buah mangrove untuk substitusi industri pangan. Jurnal Riset Teknologi Pencegahan Pencemaran Industri. 6(1): 9-15.

Neelakandan, T. dan G. Usharani 2009. Optimization and production of bioethanol from cashew apple juice using immobilized yeast cells by saccharomyces cerevisiae. AmericanEurasian Journal of Scientific Research 4: 85-88.

Pelczar, M.J., dan E.C.S. Chan. 2008. DasarDasar Mikrobiologi I. UI press, Jakarta.

Richana, N. 2011. Bioetanol: Bahan Baku, Teknologi, Produksi Dan Pengendalian Mutu. Nuansa, Bandung.

Roger, S., and E. Adelberg. 1982. Dunia Mikroba. Jilid I. Bhratara Karya Aksara, Jakarta.

Senam. 2009. Prospek Bioetanol Sebagai Bahan Bakar yang Terbarukan dan Ramah Lingkungan. Skripsi. Tidak Dipublikasikan. Jurusan Pendidikan Kimia Fakultas MIPA Universitas Negeri Yogyakarta, Yogyakarta.
Simatupang, Y.V., I M.M. Wijaya, dan N.S. Antara. 2018. Isolasi dan karakterisasi bakteri potensial penghasil etanol dari industri arak bali di karangasem-bali. Jurnal Rekayasa dan Manajemen Agroindustri. 7(1): 58-71.

Simbolon, N.C., I M.M. Wijaya, dan I.B.W. Gunam. 2018. Isolasi dan karakterisasi khamir potensial penghasil bioetanol dari industri arak di karangasem bali. Jurnal Rekayasa dan Manajemen Agroindustri. 6(4): 316-326.

Warman, A. 2017. Isolasi dan Identifikasi Aktivitas Antibakteri Bakteri Endofit Daun Pegagan (Centella aciatica L.) terhadap Escherichia coli. Skripsi. Tidak Dipublikasikan. Fakultas Kedokteran Universitas Tanjungpura, Pontianak.

Wibowo, D. 1990. Teknologi Fermentasi. Penerbit Pusat Antar Universitas Pangan dan Gizi. Universitas Gadjah Mada, Yogyakarta.

Wulandari, A., S. Bahri, dan Mappiratu. 2018. Aktivitas antibakteri ekstrak etanol sabut kelapa (Cocos nucifera linn) pada berbagai tingkat ketuaan. Jurnal Riset Kimia. 4(3): 276-284.

Wulandari, I.A.P. 2019. Optimasi Konsentrasi Yeast Extract dan Peptone pada Media Tumbuh Khamir Potensial Isolat IS 258 untuk Produksi Etanol Optimal. Skripsi. Tidak dipublikasikan. Program Studi Teknologi Industri Pertanian, Universitas Udayana, Bali 